\title{
マイコン制御による油圧シリンダ 位置決め精度向上に関する実験的研究*
}

（切換弁と電流制御式流量調整弁を用いた場合）

\author{
近藤 尚 生 ${ }^{* *}$ 山健 二**
}

\section{Experimental Study on Positioning Accuracy Improvement of Hydraulic Cylinders using a Micro-computer}

\section{-Case of using Directional Control Valve and Proportional-type Flow-control Valve-}

\author{
Hisao KONDO, Kenji YAMAGUCHI
}

In this paper, the control characteristics of a positioning accuracy improvement of hydraulic cylinders using a microcomputer are reported in the case of using a directional control valve and proportional-type flow-control valve. According to the experimental results, the positioning time has a tendency to become short when the load was added against the forward direction in method (1) and (2) among the three methods. Next, it became clear that the best suited return length of control method (3) positioned by correcting the error is three times the first overshoot $\Delta \mathrm{L}$. And, the positioning movement of the hydraulic cylinder has been simulated in the positioning accuracy and expression for calculating a limit value of the positioning accuracy has been proposed.

\section{1. 諸言}

最近，マイクロコンピュータの高機能化，低価格化 に伴い, マイコンを利用して機械可動部の動作を制御 するメカトロニクス化が盛んである。このような状況 において, 油圧シリンダ位置決め制御システムにもマ イコンが導入され, 従来の電気一油圧サーボ弁による 高精度位置決めに対しディジタル的にパルス変調で位 置決め制御を行う研究1) 99や, マイコンでサーボ弁や 電気的比例弁などを用いて制御を行う研究101-14)など が見受けられる。

本研究では, マイコンにより方向切換弁と比例制御 弁である電流制御式流量調整弁を用いた場合の油圧シ リンダ位置決め制御について, 実験的に制御特性を調 べ検討を加えた．制御特性としては，2つの制御言語 (BASIC語とマシン語) でいくつかの制御プログラム を作成し, 制御言語および制御方法による違いを実験

*昭和62年12月14日 原稿受付

**豊田工業高等専門学校

(所在地 $\bar{T} 471$ 愛知県豊田市栄生町 2-1)
的に比較検討した。また，油王シリンダに負荷を加え た場合や，位㯰決め誤差を補正しながら位置決めをす る制御方法における油㤬シリンダのもどり量を変えた 場合の制御特性についても検討した。さらに，本研究 の油圧シリンダ位置決め制御における位置決め動作の シミュレーションを行い, 奏験で測定した位㯰决め動 作と比較し，位置決め精度の限界值について検討した。 本研究による位置決め制御は, 組立機械, トランスファ マシン等のわずかな行き過ぎが許されるメカニカル オートメーション技術分野の利用が考えられる。

\section{2. 主な記号}

$k$ : 定数（離散時間系の $k$ 番目）, $k n: k$ の最終値, $\mathrm{Ke}$ : 位置センサの変位一電情:闑の比例定数, $\mathrm{Kq}$ : 流 量調整弁の電流一流量間の)比例定数, $\Delta L:$ : ストン行 き過ぎ量, $s$ : ラプラス演算子, $t:$ 経過時間, $T:$ : リンダ位置決め制御サンプリング時間, $T d$ ：ビストン 前進減速時の減速ステップ時間, $T j$ : 判定時間 $(\varepsilon \leqq \delta$ の判定), $T w$ : 待ち時間, $u$ : 比較器出力, $V:$ ヒス卜 ン速度, Vmin：ピストン最低速度, $V \max$ ：ピストン 最高速度, Vfmin：前進最低速度, Vbmin：後退最低 
速度, Vfmin $2:$ 再前進最低速度, $\Delta V:$ ピストン前進 減速時ひ減速ステップ速度, $x$ : 目標位置, $y$ : ピスト ン変位, $y^{*}: y$ をディジタル值化したもの, $\delta$ : 判定精 度, $\delta_{p}$ : 位置決め精度, $\varepsilon$ : 偏差 $\left(=x-y^{*}\right), \tau_{c}$ : パソ コン処理時間(サンブリング間隔), $\tau_{v}$ : 制御弁遅れ几時 間, $\boldsymbol{\tau}_{v r}$ : ヒイストン前進最高速度起動時制御弁遅れ時 間, $\tau_{v f}$ : ヒストン前進最高速度停止時制御弁遅れ時 間, $\tau_{v f r}$ : 前進最低速度起動時制御弁遅机時間, $\tau_{v f f}$ : 前進最低速度停止時制御弁遅机時間, $\tau_{v b r}$ : 後退最低 速度起動時制御弁遅孔時間, $\tau_{v b f}$ : 後退最低速度停止 時制御弁遅九時間

\section{3、実験装置および位置決め制御方法}

Fig，1に実験装置を示す，本実験装置は，油圧回路 部・制御部・油圧源から構成され，油圧回路部は油圧

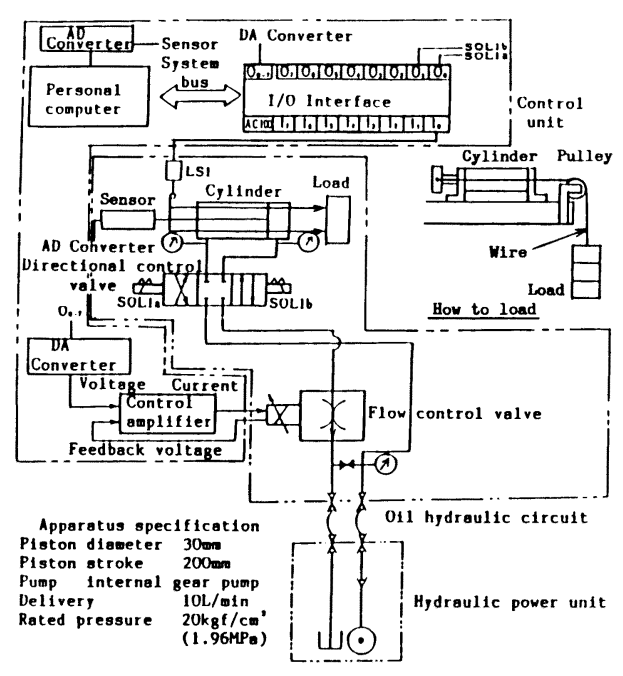

Fig. 1 Experimental apparatus

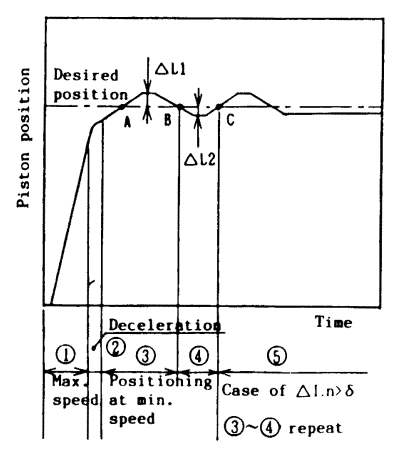

Fig. 3 Control method (2)
シリンダと, 油圧シリンダの動作速度を調節する電流 制御式流量調整弁, および動作方向を切換える切換弁 とから成る.制御部は 8 ビットパソコンを用い, I/Oイ ンターフェースを通してDA変換器・制御増幅器を介 して電流制御式流量調整弁を制御しており, 油圧シリ ンダのピストン速度を255段階設定可能である。また， 切換弁はI/Oインタフェースを通してソレノイド（1a 〜1b）を操作することにより切換え方向を制御できる ようになっている. 上記電流制御式流量調整弁および 方向切換弁の制御によるシリンダの動きは, ピストン に連動している位置センサによりピストン位置を検出 し, $\mathrm{AD}$ 変換器を介してセンサ出力をパソコンにディ ジタル值で取り込んでフィードバックしている.

本装置による油圧シリンダ位置決め制御方法は制御 プログラムで設定し, 油圧シリンダ位置決め目標位置 および位置決め許容誤差である判定精度を入力し, 制 御プログラムにより位置決め制御を行う. 位置決め制 御方法はFig. 2〜 4 に示すが, 制御方法(1), (2)は単純 な逐次比較の位置決め制御として取り上げた。制御方 法(3)は, 制御方法(1), (2)では制御弁の動作遅れ時間 $\tau_{v}$

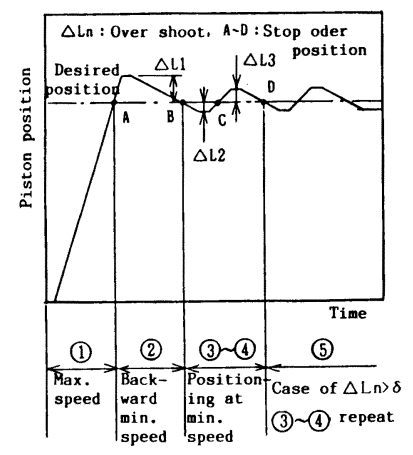

Fig. 2 Control method (1)

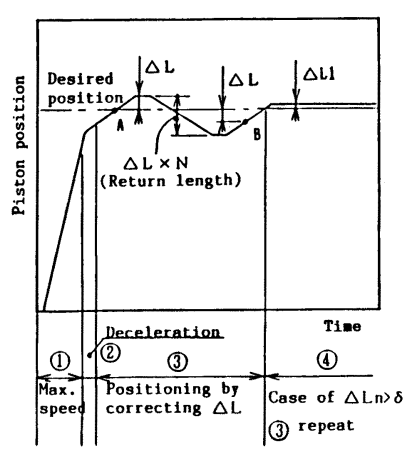

Fig. 4 Control method (3) 


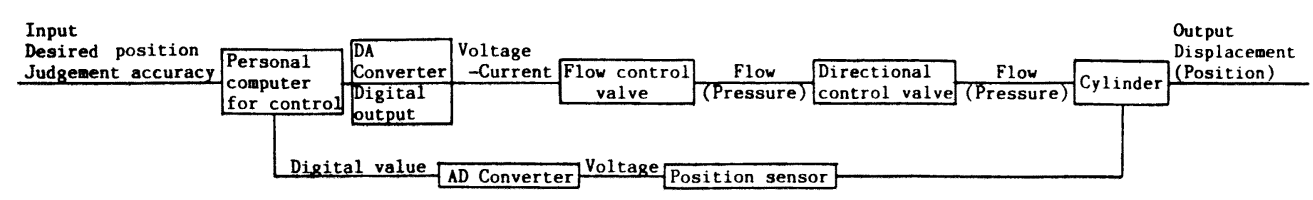

Fig. 5 Control block diagram

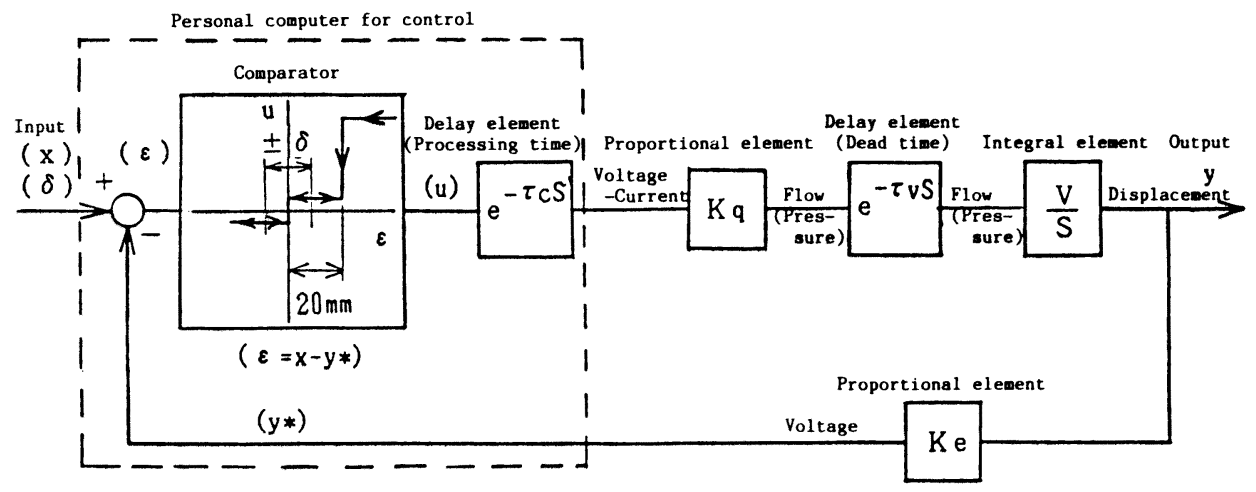

Fig. 6 Control block diagram (transfer function)

が位置決め精度に影響を与えるが,これを避ける方法 として取り上げたものである。これらのそれぞれの方 法についてBASIC語とマシン語で制御プログラムを 作成し，制御特性を実験的に調べ検討を加えた。

Fig. 1の実験装置および上述の制御方法(1)〜(3)に基 づく油圧シリンダ位置決め制御ブロック線図をFig. 5 に示す。そして, 各ブロックを制御要素別に伝達関数 で表したブロック線図をFig. 6に示す.

Fig. 6はBASIC語による制御では無視し得ないコ ンピュー夕処理時間の影響を考慮するために, 文献15) の制御ブロック線図にパソコン処理時間 $\tau_{c} に よ る$ 遅 れ要素を付加したものである. 実験では制御方法(1) 〜(3)に基づくBASIC語扔よびマシン語の制御プログ ラムにより, 負荷を変えた場合およびFig. 4の制御方 法(3)のもどり量を変えた場合の位置決め制御特性を測 定し, 比較検討する。ここで, 負荷はFig. 1に示す位 置でピストン前進方向と逆方向に $5 \mathrm{kgf}(49 \mathrm{~N}), 10 \mathrm{kgf}$ $(98 \mathrm{~N}), 15 \mathrm{kgf}(147 \mathrm{~N})$ の慣性負荷を加えたものであ る.また, ピストン動作時の摩擦も含めた粘性抵抗は, 最低速度で $54 \mathrm{kgf} \cdot \mathrm{s} / \mathrm{m}(530 \mathrm{~N} \cdot \mathrm{s} / \mathrm{m})$, 最高速度で $9000 \mathrm{~kg}$ $\mathrm{f} \cdot \mathrm{s} / \mathrm{m}(88 \mathrm{kN} \cdot \mathrm{s} / \mathrm{m})$ であり, 中間の速度ではその間の 数值であった。

\section{4. 油圧シリンダピストン功作の解析}

次に油圧シリンダの位置決め制御時のピストン動作 シミュレーション, および位置決め精度限界值につい

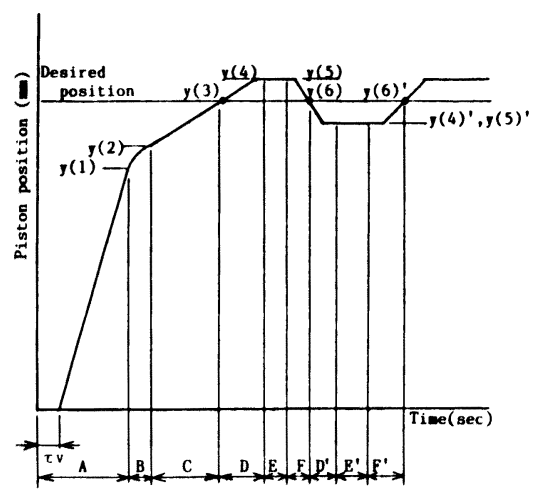

Fig. 7 Piston movement of control method (2)

て述べる。

4.1 ピストン動作シミュレーション

Fig. 2〜 4 に示す油圧シリンダ位置決め制御方法(1) 〜(3)のうち, 制御方法(2)についてのピストン動作シ ミュレーション方法を述べる. 制御方法(1), (3)につい ても制御方法(2)と同様の考え方でシミュレーションで きるので,ここでは省略する. 制御方法(2)のピストン 動作図をFig.7に示す.Fig.7によれば，ピストン動 作は $\mathrm{A} \sim \mathrm{F}, \mathrm{D}^{\prime} \sim \mathrm{F}^{\prime}$ の動作領域からなっており, 各動作 領域についてFig. 6の制御ブロック線図の各制御要素 から経過時間 $t$ とピストン変位 $y$ の関係式を求める。そ

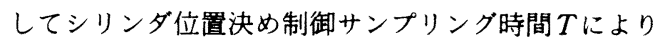
$t$ と $y$ の関係式を離散化することにより, マイコン制御 
による油圧シリンダ位置决めのピストン動作シミュ レーションを行う. 以下, Fig. 7の各動作領域のピス トン変位を求めるが，その前提条件を列挙し，そして 前提条件に基づく各関係式を示す.

\section{前提条件}

・油漏れ，油の圧縮性，負荷の慣性を無視し伝達関数 を簡単にした場合について行う。

・ピストン速度を最高速度から減速する位置は，目標 位置手前 $20 \mathrm{~mm}$ よ小さくなったことを検出した時点 で行う。

・減速は25段階で等速減速で行う.

・目標位置に対するピストン停止命令は, 目標位置を 行き過ぎたことを検出した時点で行う。

・位置決め精度が判定精度以内に納まるまで位置決め 動作（目標位置をはさんで前進，後退）を繰り返す。

・制御弁の遅れ時間を考慮して，ピストン停止命令を 出力後待ち時間を設け，ピストンが完全に停止後位 置決め精度の判定を行う。

こピストン動作関係式

$\mathrm{A}$ 領域 $\left(0 \leqq y_{A}(t)<x-20\right)$ - 最高速度領域 連続時間系で㳉

$$
\begin{aligned}
& y_{A}(t)=V \max \left(t-\tau_{v r}\right) \\
& \quad\left(\text { 但 } t-\tau_{v r} \leqq 0 \text { で } y_{A}(t)=0\right)
\end{aligned}
$$

上式をサンプリング時間 $T$ により離散時間系にすると

$$
\begin{aligned}
y_{A}(k T)=V \max & \left(k T-\boldsymbol{\tau}_{v r}\right) \\
y_{A}\{(k+1) T\} & =V \max \left\{(k+1) T-\tau_{v r}\right\} \\
& =V \max \cdot T+y_{A}(k T)
\end{aligned}
$$

(但し $k T-\tau_{v r} \leqq 0 て ゙ y_{A}(k T)=0$ )

初期条件 $y_{A}(0)=0$

$$
y(1)=y_{A}(k n T)+V \max \left(2 T+\tau_{v f}\right)
$$

以下 $\mathrm{A}$ 領域と同様の考え方で離散時間系で表す.

\section{$\mathrm{B}$ 領域——減速領域}

$$
\begin{gathered}
y_{B}(k T d)=(V \max -k \Delta V) T d+y(1) \\
y_{B}\{(k+1) T d\}=\{V \max -(k+1) \Delta V\} T d \\
+y_{B}(k T d) \\
y(2)=\left(V \max -k_{25} \Delta V\right) T d+y_{B}\left(k_{24} T d\right)
\end{gathered}
$$

$\mathrm{C}$ 領域 $\left(y_{c}(t)<x\right)$ 以下最低速度領域

$$
\begin{aligned}
& y_{c}(k T)=(V f m i n(k T)+y(2) \\
& y_{c}\{(k+1) T\}=V f m i n \cdot T+y_{c}(k T) \\
& y(3)=V f \min \cdot T+y_{c}(k n T)
\end{aligned}
$$

\section{$\mathrm{D}$ 領域}

$$
\begin{aligned}
& y_{D}(k T)=V f \min \left(\boldsymbol{\tau}_{v f f}+T\right)+y(3) \quad(k=1 \text { のみ }) \\
& y(4)=y_{D}(k T)
\end{aligned}
$$

$\mathrm{E}$ 領域

$$
y(5)=y(4)
$$

$\mathrm{F}$ 領域 $\left(y_{F}(t)>x\right)$

$$
\begin{aligned}
& y_{F}(k T)=y(5)-V b \operatorname{Vmin}\left(k T-\tau_{v b r}\right) \\
& y_{F}\{(k+1) T\}=-V b \operatorname{Vmin} \cdot T+y_{F}(k T) \\
& \quad\left(\text { 但し } \quad k T-\tau_{v b r} \leqq 0 \text { でy } y_{F}=y(5)\right) \\
& y(6)=-V b \min \cdot T+y_{F}(k n T)
\end{aligned}
$$

D'領域

$$
\begin{aligned}
& y_{D}{ }^{\prime}(k T)=y(6)-\operatorname{Vbmin}\left(\tau_{v b f}+T\right) \quad(k=1 \text { のみ }) \\
& y(4)^{\prime}=y_{D}{ }^{\prime}(k T)
\end{aligned}
$$

E'領域

$$
y(5)^{\prime}=y(4)^{\prime}
$$

$\mathrm{F}^{\prime}$ 領域 $\left(y_{F}^{\prime}(t)<x\right)$

$$
\begin{aligned}
& y_{F}{ }^{\prime}(k T)=V f \min 2 \cdot\left(k T-\tau_{v f r}\right)+y(5), \\
& y_{F}{ }^{\prime}\{(k+1) T\}=V f \min 2 \cdot T+y_{F}{ }^{\prime}(k T) \\
& \quad\left(\text { 但し } \quad k T-\tau_{v f r} \leqq 0 \text { で } y_{F}{ }^{\prime}=y(5){ }^{\prime}\right) \\
& y(6)^{\prime}=y_{F}{ }^{\prime}(k n T)+V f \min 2 \cdot T
\end{aligned}
$$

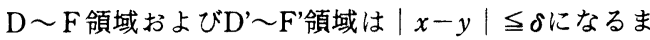
で繰り返す。

以上の(1)式〜(21)式と Fig. 7に示すピストン動作図に よりピストン動作シミュレーションを行う。

\section{2 位置決め精度限界値}

4.1 に示したピストン動作シミュレーションの考え 方に基づいた目標位置付近のピストン動作をFig. 8, 9 に示す。Fig. 8よりわかるように, 制御方法(1)，(2) では，パソコン処理時間 $\boldsymbol{\tau}_{c}$ と制御弁遅れ時間 $\boldsymbol{\tau}_{v} に よ り$ 目標位置に対し行き過ぎ量が出る，また，Fig，9より わかるように，制御方法(3)は制御方式(1)，(2)で起こる 前進方向 $\Delta L$ の行き過ぎ量を，再前進時に目標位置の $\Delta L$ 手前で停止命令を出して補正する方法であるため,

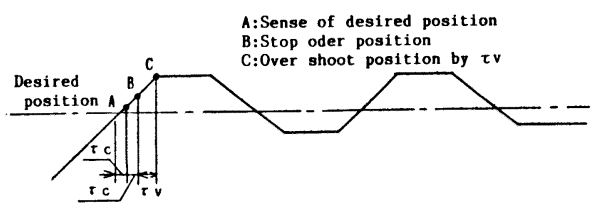

Fig. 8 Piston movement near by desired position (Control method (1), (2))

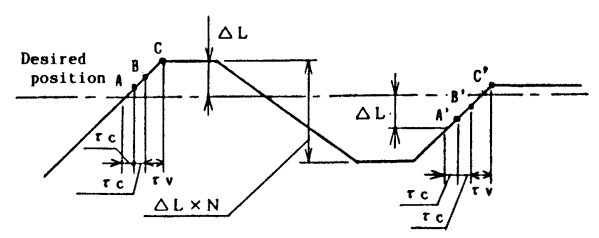

Fig. 9 Piston movement near by desired position (Control method (3)) 
$\left(\tau_{v}+\tau_{c}\right)$ の遅れ時間による行き過ぎ量は補正され る.したがって, 制御方法(1)〜(3)による位置決め精度 の限界值は以下の式により求められる。

○制御方法(1), (2)の場合

$$
V \min \times\left(\boldsymbol{\tau}_{c}+\boldsymbol{\tau}_{v}\right) \leqq \delta_{p}<V \min \times\left(2 \boldsymbol{\tau}_{c}+\boldsymbol{\tau}_{v}\right) \quad \text { (22) }
$$

$\bigcirc$ 制御方法(3)の場合

$$
0 \leqq \delta_{p}<V \min \times \boldsymbol{\tau}_{c}
$$

上式より前進および後退時の $V \min , \boldsymbol{\tau}_{v}$ と, BASIC語 とマシン語制御の時の $\boldsymbol{\tau}_{c}$ を測定し, 位置決め精度の限 界值が計算できる。この計算值と実際に位置決め制御 を行い測定した位置決め精度の実験値との比較は次章 に示す。

\section{5. 実験結果}

\section{1 負荷と制御特性の関係}

Fig. 10，11に負荷と制御特性の関係を示す.実験点 は 5 回測定した平均値をとっている. 負荷は本実験装 置の油圧回路上最大 $18 \mathrm{kgf}(176.4 \mathrm{~N})$ であるので $0 \sim 15$ kgf（147N）まで実験を行った。

Fig. 10によれば, BASIC語制御方法(1)，(2)では負荷 により位置決め精度はほとんど変化しない, 位置決め 時間は, 判定精度が $0.3 \mathrm{~mm}$ と厳しい場合は, 負荷を大き くすると短くなる傾向を示す。これは位置決め精度の 限界值に近づくと Fig. 2，3に示す(3)〜(4)の繰り返し 回数が多くなり, 最低速度前進起動時のピストン速度 が定常速度よりも速くなる現象が負荷により抑えられ， 前進方向の行き過ぎ量が小さくなり位固決め時間が短 くなったものである.

次にFig. 11のBASIC語制御方法(3)については，位 置決め精度, 位置決め時間共に負荷によりほとんど変 化しない. 制御方法(3)はFig. 4より行き過ぎ量を検出 記憶し, それを補正して位置決めを行うために, 負荷 が変化してもそれに対応するため安定した制御特性が 得られる. マシン語制御の場合も負荷と制御特性の関 係はほぼ同様の傾向がみられた。

\section{2 もどり量と制御特性の関係}

3 種類の制御方法のうち, 制御方法(3)はFig. 4 亿示 すように行き過ぎ量 $\Delta L$ の $\mathrm{N}$ 倍のもどり量だけ一旦後 退し, 再前進時に目標位置より $\Delta L$ 手前の B点で停止命 令を出して行き過ぎ量 $\Delta L$ を補正しながら位置決めを 行う方法である。一旦ピストンを行き過ぎ位置から後 退させて再前進させるのは, ピストン前進と後退でピ ストン速度, 制御弁遅れ時間が異なるためである。こ の制御方法(3)についてもどり量と制御特性の関係の実 験結果をFig.12,13に示す.Fig.12,13によればBASIC 語, マシン語制御共にもどり量に対し位置決め精度は

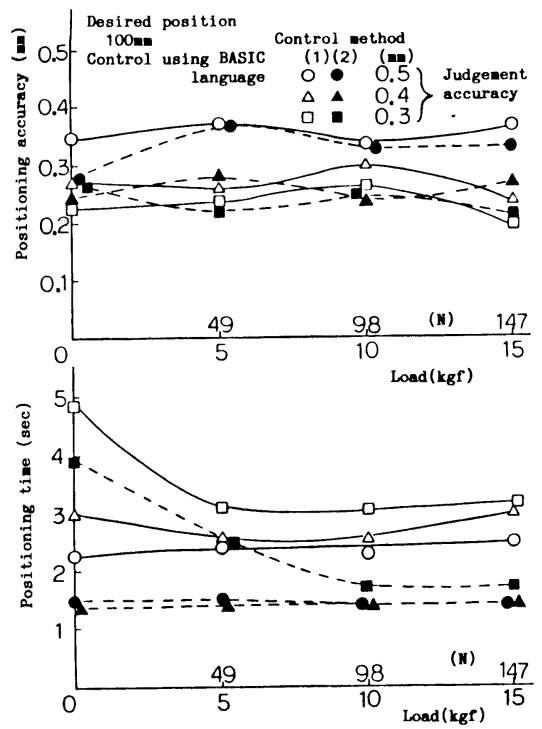

Fig. 10 Relation of control characteristics to load
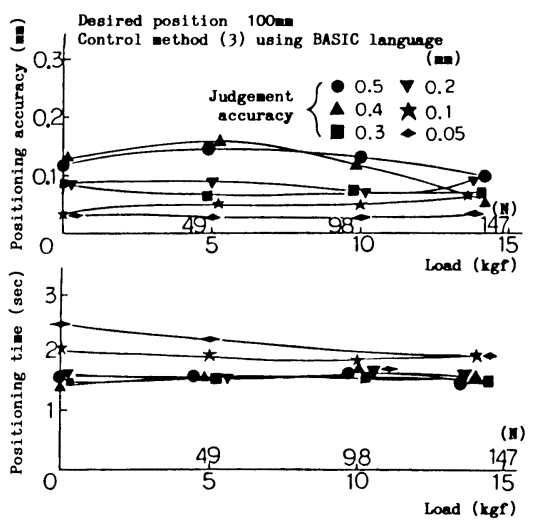

Fig. 11 Relation of control characteristics to load

ほぼ一定である。また，位置決め時間はもどり量が大 きくなるほど長くなる傾向を示す。しかし，もどり量 が $\Delta L の 2$ 倍ではもどり量が小さすぎ，再前進時のピス トン起動直後の速度が定常最低速度 V minよりかなり 速くなり行き過ぎ量 $\Delta L を$ 補正できず, また, 位置決め 動作も異常になって位置決め不能となるため, 制御方 法(3)の場合もどり量はFig. 4のB点でピストンが十分 定常速度になる 3 倍が適当であると考えられる。

\section{3 位置決め精度の検討}

Fig. 14に目標位置 $100 \mathrm{~mm}$, 無負荷時の制御方法(1) 〜(3)とBASIC語，マシン語の制御特性の比較を示す. Fig. 14の制御方法(3)は5.2よりもどり量を 3 倍とし ている. 


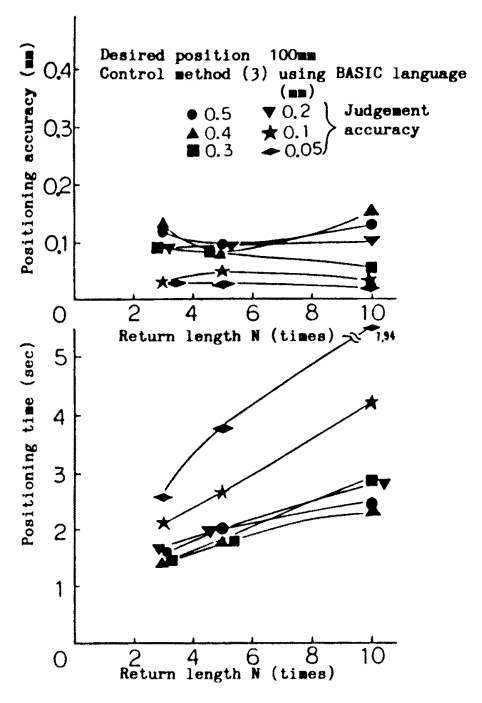

Fig. 12 Relation of positioning accuracy to return length

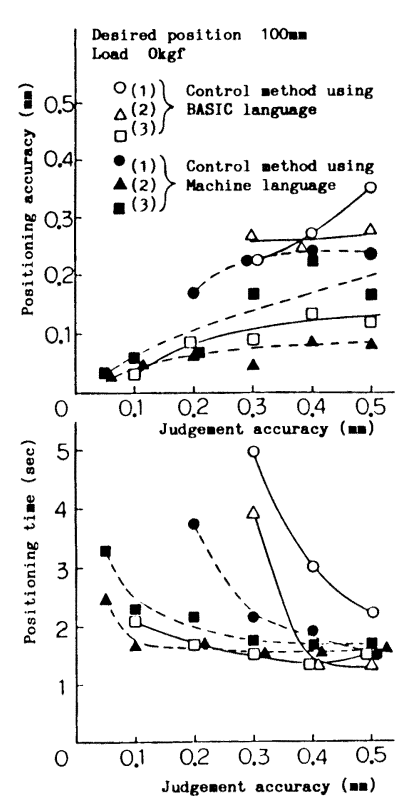

Fig. 14 Comparison of control characteristics

また，Fig．15にBASIC語制御方法(2)を例にピスト ン動作を観測した図を示す。まず，位置決め精度を前 述の式(22)，(23)より計算する。ここで計算に必要な Vmin，列はFig. 15に一例を示すピストン動作図より 読み取った。また， $\tau_{c}$ はパソコン内蔵夕イマにより $\tau_{c}$ 測定用プログラムを作成して実測した。 以上の項目の 実測結果をTable 1に示す.なお, Table 1 の $\tau_{v}$ は位置

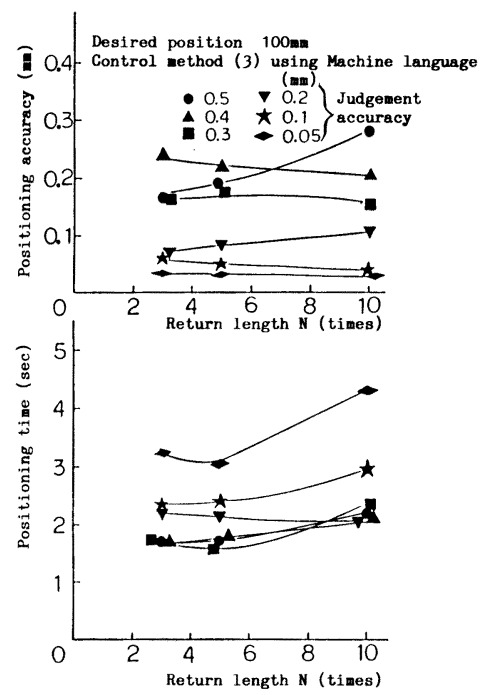

Fig. 13 Relation of positioning accuracy to return length

Table 1 Measurement value

\begin{tabular}{|c|c|c|}
\hline & Piston forward & Piston back \\
\hline$V \min$ & $6.5 \mathrm{~mm} / \mathrm{s}$ & $4.5 \mathrm{~mm} / \mathrm{s}$ \\
\hline$\tau_{v}$ & $32 \mathrm{~ms}$ & $40 \mathrm{~ms}$ \\
\hline & $\begin{array}{l}\text { Control using } \\
\text { BASIC language }\end{array}$ & $\begin{array}{l}\text { Control using } \\
\text { Machine language }\end{array}$ \\
\hline$\tau_{c}$ & $16 \mathrm{~ms}$ & $0.4 \mathrm{~ms}$ \\
\hline
\end{tabular}

Table 2 Calculation value of $\delta_{p}$

\begin{tabular}{|c|l|l|}
\hline $\begin{array}{l}\text { Control } \\
\text { method }\end{array}$ & $\begin{array}{l}\text { Control using } \\
\text { BASIC language }\end{array}$ & $\begin{array}{l}\text { Control using } \\
\text { Machine language }\end{array}$ \\
\hline$(1),(2)$ & $0.25 \leqq \delta_{p}<0.42$ & $0.18 \leqq \delta_{p}<0.21$ \\
\hline$(3)$ & $0 \leqq \delta_{p}<0.10$ & $0 \leqq \delta_{p}<0.0026$ \\
\hline
\end{tabular}

決め精度に直接関係する $\tau_{v f f}, \tau_{v b f}$ の值をそれぞれピ ストン前進, 後退の $\boldsymbol{\tau}_{v}$ の值としている.このTable 1 の值と式(22), (23)より位置決め精度を計算したものを Table 2に示す.

Fig.14の実験結果によれば, 位置決め精度はBASIC 語制御方法(1)〜 (3)およびマシン語制御方法(1)はほぼ Table 2 の $\delta_{p}$ の範囲に入っている. マシン語制御方法(2) は計算值より小さく, 制御方法(3)は大きく出ているが, 方法(3)についてはピストン最低速度起動時の定常速度 との違いが影響していると考えられる。次に, 制御言 


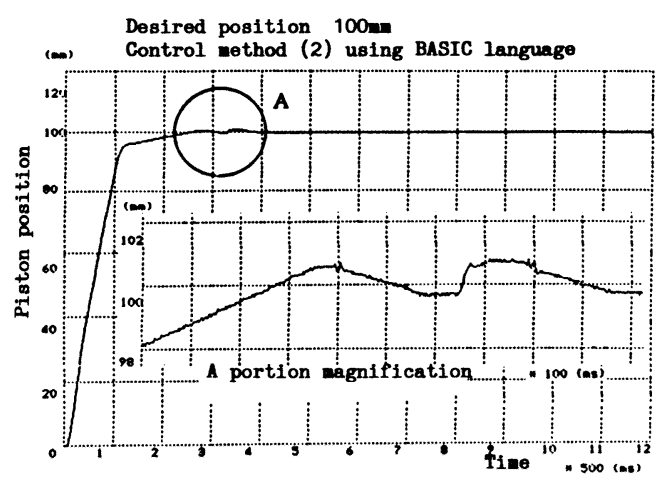

Fig. 15 Piston movement (observation)

語と制御方法の違いによる制御特性を比較すると, BASIC語制御では制御方法(3)，マシン語制御では制御 方法(2)による特性が良好である. BASIC語制御でも行 き過ぎ量を補正しながら位置決めを行う制御方法(3)を 用いれば、マシン語制御方法(2)に近い制御特性が得ら れることがわかる。位置決め時間については, Fig. 14 より位置決め精度限界值近傍で増大することがわかる。

Fig. 16は4.1で述べたピストン動作シミュレー ションによりBASIC語制御方法(2)についてシミュ レートした結果を示す.Fig. 16は実際に観測したFig. 15のピストン動作にほぼ合っており, 負荷が小さく配 管の油が大きくない場合, 4.1 の方法でシミュレート できることがわかった。

\section{5. 結专}

マイコンにより方向切換弁と電流制御式流量調整弁 を用いた場合の油圧シリンダ位置決め制御について, 実験的に制御特性を検討した結果次の結論が得られた。 （1）前進を妨げる方向に負荷を加えることにより，ピ ストン最低速度前進起動時に定常速度より速くなる現 象が抑えられ，制御方法(1)，(2)については位置決め時 間が短くなる傾向にある。

（2）制御方法(3)のもどり量は本実験装置の場合 3 倍が 適当である。

（3）位置決め精度はマシン語制御方法(2)，(3)でやや外 れるが, 式(22), (23)より位置決め精度の範囲が求められ ることが明らかとなった。

（4）制御言語と制御方法の違いによる制御特性を比較 すると, BASIC語制御では制御方法(3)，マシン語制御 では制御方法(2)が良好である。

（5） Fig. 5〜 6のブロック線図を基に位置決め制御時 のピストン動作シミュレーションができることがわ

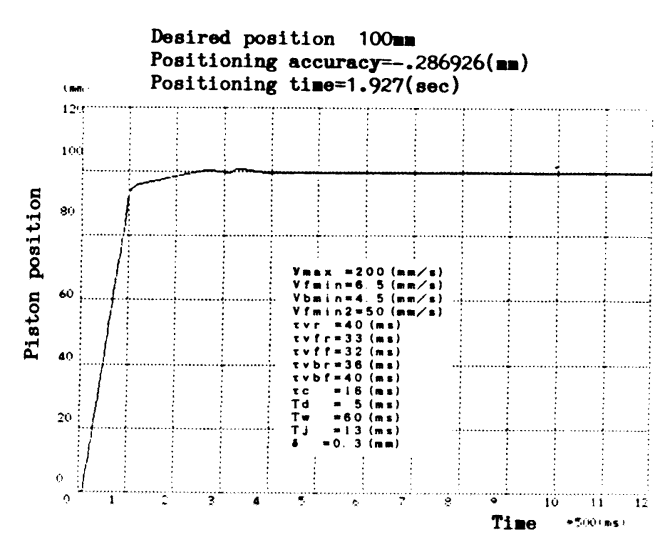

Fig. 16 Piston movement (simulation)

かった。

\section{考文献}

1) 田中, 内山, 木嶋, 小笠：エア・八イドロ方式空 気圧シリンダのマイクロコンピュータによる位置 決め, 昭和55年秋季油空圧講論, 27/30, (1980)

2) 原田, 小山, 海保: 空気圧ピストンのディジタル 位置制御, 昭和 56 年春季油空圧講論, $5 / 8,(1981)$

3 ) 山藤, 小笠原, 真木 : 空気圧のシリンダ位置制御, 昭和59年秋季油空圧講論, $5 / 8,(1984)$

4 ) 田中裕久, 田中弘義, 荒木: 三方向形高速電磁弁 の電子油圧ディジタル制御, 機論, $50-458 \mathrm{~B}$, 2663/2666, (1984)

5 ) 小柳, 小嶋, 品田: 自己学習機能を有する電子油 圧ディジタル位置制御システムの設計と性能, 油 圧と空気圧, 18-2，139/147，(1987)

6 ）花房, 則次 : 空気圧シリンダの高精度位置決めの ための圧力制御方式，機論，47-415，328/336, (1981)

7 ) 則次, 花房 : 空気圧シリンダのパルス幅変調方式 速度制御一低速駆動時に扔ける一定速度送り一, 油圧と空気圧，14-7，505/512，(1983）

8 ) 則次：パルス幅変調方式による電気・空気圧サー ボ系の構成, 計測自動制御学会論文集, $20-8$, 754/761，(1984)

9 ) 花房, 則次, 浅野: 空気圧シリンダの計算機制御, 昭和55年春季油空圧講論，53/56，（1980)

10）石田，小川，藤原，小根山：電空比例弁を用いた 空気圧シリンダのマイコンによる位置決め制御に ついて，昭和56年春季油空圧講論， $9 / 12 ，(1981)$

11）浅沼, 石田, 小川, 藤原：学習機能を持つロック アッブ機構付空気圧シリンダの位置決め装置, 昭 
和58年春季油空圧講論，83/86，（1983）

12）竹林, 石田, 小川, 藤原：空気圧シリンダの位置 決め速度制御について, 昭和 59 年秋季油空圧講論, $13 / 16, \quad(1984)$

13）加世田, 小山, 原田：電気空気圧サーボ方式によ るピストンシリンダの位置決め, 昭和 60 年秋季油
空圧講論, 21/24, (1985)

14）高木, 江崎 : 空気圧シリンダの学習的位置制御, 機論，50-459B，2823/2828，(1984）

15）本間：電気油圧オンオフ制御系の特性と設計のポ イント, 油圧と空気圧, $13-4,238 / 244$, (1982)

\section{会告}

\begin{tabular}{|c|c|c|c|c|c|c|}
\hline 摘要 & 名誉会員 & 正 会 員 & 学生会員 & 賛助会員 & 合 & 計 \\
\hline $\begin{array}{l}63.11 .15 \\
\text { 会 } \quad \text { 員 数 }\end{array}$ & 3 & 1,104 & 32 & 81 & & 1,220 \\
\hline $\begin{array}{l}\text { 元. } 1.15 \\
\text { 会 } \quad \text { 員 } \\
\text { 数 }\end{array}$ & 3 & 1,099 & 33 & 89 & & 1,217 \\
\hline 差引増減 $(\triangle)$ & 0 & $\triangle$ & 1 & 8 & & 4 \\
\hline
\end{tabular}

[入会者名]

(正) 高

中 原 盛 夫（日本エヤーブレーキ(侏）

田中忠夫(三菱自動車工業(俶)

吉田竟(三菱自動車工業(侏)

(学) 需宗 強 (哈尔濱工業大学)
新 谷 隆 二(石川県工業試験場)

金憘 南 (朝鮮大学)

森田隆 夫 (三菱自動車工業(侏)) 